\title{
Rancang Bangun Aplikasi Mobile Survey Pendamping Program Keluarga Harapan (Studi Kasus: UPPKH Dinas Sosial dan Tenaga Kerja Kota Batu)
}

\author{
Mukhammad Rojib Saiful Arif ${ }^{1}$, Galih Wasis Wicaksono², Nur Hayatin ${ }^{3}$ \\ Program Studi S1 Teknik Informatika Universitas Muhammadiyah Malang \\ rojibsaiful@gmail.com, ${ }^{2}$ galih.w.w@umm.ac.id, ${ }^{3}$ noorhayatin@umm.ac.id
}

\begin{abstract}
Abstrak
UPPKH Dinas Sosial dan Tenaga Kerja Kota Batu ini, merupakan satu dari beberapa instansi pemerintah yang belum menerapkan sistem informasi manajemen pengolahan data dan masih melakukan input data di setiap aktivitasnya masih secara manual. Hal itu menjadikan kendala bagi instansi pemerintahan tersebut untuk meningkatkan kinerja para pendamping dalam menyediakan informasi yang efektif dan efisien. Pengolahan data yang masih manual ini menimbulkan berbagai masalah. Diantaranya yang timbul dari permasalahan pendamping dalam menjalankan tiap tugasnya harus menunggu data dari admin untuk survei ke setiap calon anggota peserta PKH. Dan permasalahan yang lain yaitu sulitnya admin untuk mengetahui informasi laporan data $\mathrm{PKH}$. Dan untuk mengatasi permasalahan yang ada pada kasus ini penulis menganalisis dan merancang sebuah aplikasi yang diharapkan dapat membantu tugas para pendamping dan admin, dimulai dari pengumpulan data menggunakan wawancara, observasi, dan penelitian kepustakaan. Dan aplikasi yang digunakan dalam implementasi sistem, yaitu database MySQL, Webservice, PHP Codeigniter dan Android sebagai bahasa pemrogramannya. Sistem ini mengintegrasikan aplikasi android dengan aplikasi web based menggunakan web service. Web Service menyediakan standar komunikasi di antara berbagai aplikasi software yang berbeda dan dapat berjalan di berbagai platform maupun framework. Sistem ini dibuat untuk membantu mempercepat proses penyelesaian pekerjaan seperti pada proses pendamping dan admin.
\end{abstract}

Kata kunci: Pengolahan Data PKH, web service, android, PHP codeigniter

\section{PENDAHULUAN}

Kemajuan dan perkembangan teknologi, khususnya teknologi informasi menjadikan sebuah informasi yang dapat dengan mudah kapan pun dan dimana pun diimplementasikan. Berkembangnya teknologi tersebut telah mengubah pola dalam menjalankan aktivitas, sebuah perusahaan/instansi untuk beringinan terus berkembang serta menggapai kesuksesan sebagai sebuah visi utama yang ingin dicapai, dengan perkembangan dunia saat ini disertai bermunculannya kesulitan yang tidak bisa ditebak mau tidak mau suatu perusahaan/instansi harus terus berinovasi untuk dapat meningkatkan pelayanan terhadap masyarakat.

Sebagian besar instansi pemerintahan khususnya dalam studi kasus pada tugas akhir peneliti ini adalah UPPKH Dinas Sosial dan Tenaga Kerja Kota Batu, yang masih menggunakan cara manual dalam mengelola data peserta program keluarga harapan (PKH). Hal ini menjadi kendala dan hambatan bagi instansi pemerintahan tersebut untuk meningkatkan kinerja para pendamping PKH dalam menyediakan informasi yang efektif dan efisien. Pengolahan data yang masih manual menimbulkan berbagai masalah. Diantaranya timbul dari permasalahan adalah penyampaian informasi data PKH dan penyampaian operator/admin PKH masih memakan waktu yang lama diakibatkan semua kebutuhan masih dengan cara input manual. Permasalahan pendamping PKH dalam menjalankan tiap tugasnya harus menunggu data dari operator/admin PKH untuk survei ke setiap calon anggota peserta PKH. Dan permasalahan yang lain adalah kesulitan pada operator/admin PKH untuk mengetahui informasi tiap laporan data PKH.

Sehubungan dengan kondisi tersebut, Maka muncul gagasan dari peneliti untuk membuat suatu pengembangan yaitu sistem aplikasi, 
khususnya tentang manajemen pengolahan data PKH yang lebih efektif dan efisien berbasis online, sehingga dapat diakses oleh pendamping yang membutuhkan data PKH untuk survey dimana saja.

Berdasarkan masalah yang ada, penulis berkeinginan untuk mengatasi persoalan dengan membuat sebuah penelitian ilmiah yang berjudul "Rancang Bangun Aplikasi Mobile Survey Pendamping Program Keluarga Harapan (PKH) (Studi Kasus: UPPKH Dinas Sosial dan Tenaga Kerja Kota Batu)".

\section{METODE PENELITIAN}

Penelitian ini dilakukan dengan metode-metode sebagai berikut:

1. Pengumpulan Data

a. Studi Kepustakaan

Dengan mempelajari berbagai permasalahan yang berkaitan dengan manajemen pengolahan data dan pembuatan laporan PKH yang masih dilakukan secara manual. Proses pembelajaran materi dilakukan dengan kajian berbagai sumber pustaka baik berupa buku, jurnal ilmiah, dan media elektronik.

b. Metode Wawancara

Pengumpulan suatu informasi dengan cara mengajukan pertanyaan secara lisan dan dijawab secara lisan pula. Mengadakan tanya jawab dengan Pihak Instansi UPPKH Dinas Sosial dan Tenaga Kerja Kota Batu dan mencatat data-data yang diperlukan oleh sistem dan untuk mendapatkan gambaran tentang sistem pengolahan data $\mathrm{PKH}$ manual beserta atribut-atribut yang dimiliki pihak instansi terkait.

\section{Analisa Kebutuhan}

Pada tahap ini akan di lakukan analisis data yang telah didapat dan merancang sistem dari data yang telah terkumpul sehingga dapat dijadikan acuan dalam pembuatan sistem. Analisa kebutuhan terdiri dari analisa kebutuhan fungsional, kebutuhan nonfungsional, merancang desain arsitektur sistem, Use Case Diagram, Activity Diagram, Sequence Diagram, dan Class Diagram.

3. Implementasi

Implementasi sistem dilakukan dengan mengacu pada perancangan sistem yang sudah dibuat. Implementasi yaitu memindahkan suatu bentuk design dalam suatu bahasa yang bisa dikenali oleh piranti komputer. Pada tahap ini merupakan tahapan nyata dalam pembuatan suatu sistem mobile survey PKH pendamping. Proses Implementasi ini menggunakan komponen komponen java android, php, dan MySQL, seperti: SDK, JDK, Android Studio dan Web Based menggunakan PHP Editor dengan framework CI.

\section{Pengujian}

Pengujian dilakukan untuk mengetahui bahwa sistem yang dibuat bekerja dengan baik dan sistem sudah sesuai dengan tujuan penelitian. Pengujian yang dilakukan ada 2 cara yaitu, pengujian Black-box dan pengujian User Acceptance Test (UAT). Pengujian Black- box memfokuskan pada keperluan fungsional dari sistem aplikasi. Karena itu pengujian Black-box memungkinkan pengembang sistem aplikasi untuk membuat himpunan dalam bentuk kondisi input yang akan melatih seluruh syarat - syarat fungsional untuk suatu sistem yang akan dibuat. Pengujian User Acceptance Test (UAT) adalah pengujian yang dilakukan oleh pengguna sistem untuk memastikan fungsi - fungsi yang ada pada sistem apakah telah berjalan dengan baik dan sesuai dengan kebutuhan pengguna.

5. Pengambilan Kesimpulan

Kesimpulan diambil guna merangkum hasil yang keseluruhan dari penelitian. Kesimpulan berisi tentang jawaban atas pertanyaan peneliti yang diajukan pada bagian rumusan masalah. Kesimpulan didapatkan dari penelitian yang terkait dengan implementasi sistem dan hasil yang diperoleh.

\section{Analisa dan Perancangan Sistem} Analisa Sistem

1. Android

Android merupakan sebuah sistem operasi telepon seluler dan komputer tablet layar sentuh (touch screen) yang berbasis Linux. 


\section{Framework Codeigniter}

CodeIgniter adalah sebuah

framework PHP. Framework merupakan struktur penting yang berada di sebuah folder yang memuat sebuah file php yang menyediakan class libraries, helpers, plugins dan lainnya. Framework disini menyiapkan sebuah konfigurasi dan teknik programming. Dan tujuan utama dalam pengembangan codeigniter untuk membantu developer mengerjakan sebuah aplikasi agar lebih cepat dibandingkan menulis semua code dari awal. Codeigniter menyediakan berbagai library yang dapat mempermudah dalam pengembangan suatu sistem aplikasi.

Perancangan Sistem

Berikut adalah Arsitektur Sistem Aplikasi Mobile Survey Pendamping PKH pada Studi Kasus: UPPKH Dinas Sosial dan Tenaga Kerja Kota Batu

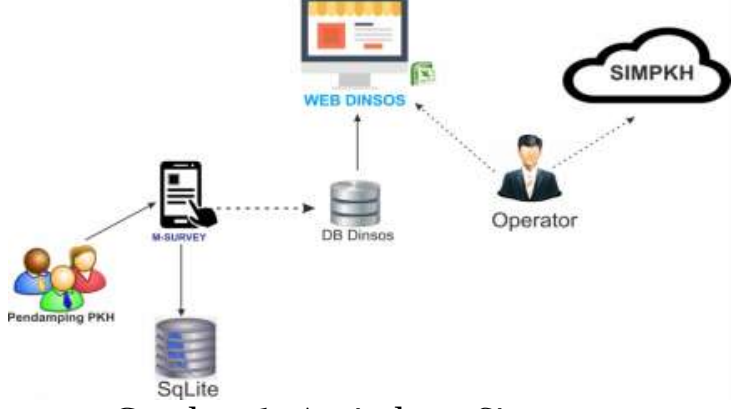

Gambar 1. Arsitektur Sistem

Pada arsitektur sistem manajemen mobile survey pendamping $\mathrm{PKH}$, terdapat dua aplikasi yaitu aplikasi android untuk pendamping dan aplikasi manajemen untuk admin PKH. Kedua aplikasi mengakses data Dinsos yang sama yang berada dalam server Dinas sosial. Data yang berada di server diakses oleh kedua aplikasi client. Hubungan antara client dan server tidak terjadi secara langsung. Hubungan antara client dan server dihubungkan oleh file web services yang sudah ditentukan dalam format tertentu. Sehingga akses terhadap database akan ditangani tidak secara langsung oleh server, melainkan melalui perantara yang disebut sebagai web services tersebut. Peran dari web services ini diharapkan mempermudah distribusi sekaligus integrasi antara kedua aplikasi yang akan dibuat. Web service digunakan untuk menyediakan layanan (dalam bentuk informasi) kepada kedua sistem tersebut, sehingga kedua sistem dapat berinteraksi melalui layanan layanan (service) yang disediakan oleh suatu web.

\section{Hasil Penelitian dan Pembahasan}

Pada tahap ini akan dijelaskan hasil dan pembahasan dari penelitian tentang Aplikasi Mobile Survey Pendamping PKH pada Studi Kasus: UPPKH Dinas Sosial dan Tenaga Kerja Kota Batu. Implementasi Sistem

Tampilan Halaman Utama Admin 1. Login

Pada halaman
menampilkan form login untuk
pendamping PKH.

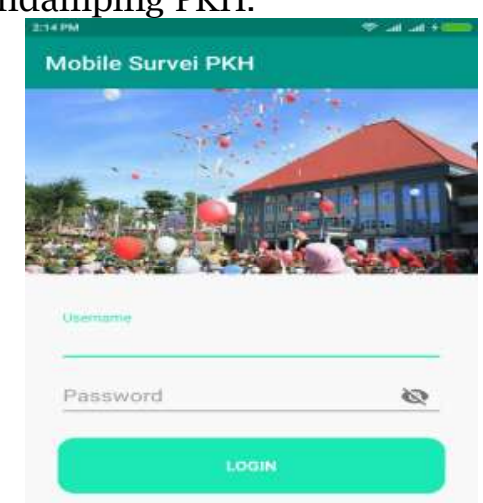

Gambar 2 Halaman Login Pendamping

2. Halaman Utama

Pada halaman aplikasi mobile survey pendamping PKH menampilkan beberapa menu daftar $\mathrm{PKH}$, profile pendamping, insert kegiatan, about, dan logout. Halaman utama ini ditampilkan saat pertama kali pendamping melakukan login.

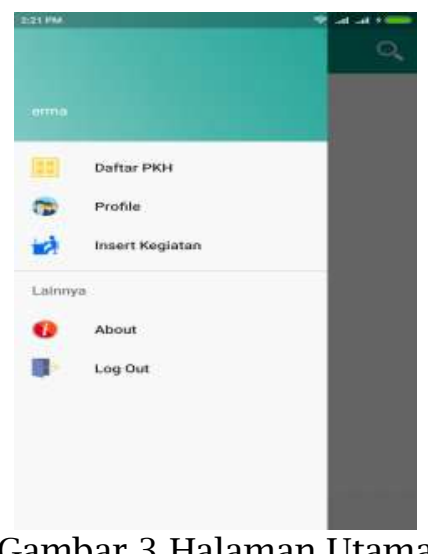

Gambar 3 Halaman Utama 


\section{Daftar PKH} Pada

\section{halaman}

aplikasi menampilkan beberapa member peserta PKH, yang nantinya bila salah satu nama di klik akan memunculkan beberapa menu yang bisa dilihat dan di update oleh pendamping PKH.

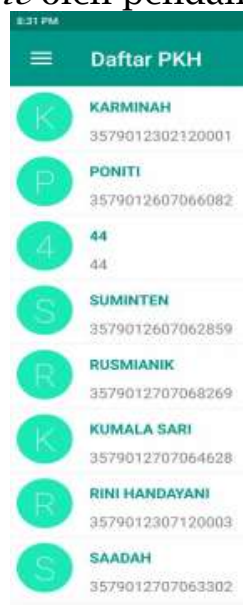

Gambar 4 Halaman Daftar PKH

\section{Data PKH}

Pada halaman aplikasi, pendamping setelah memilih salah satu nama peserta PKH akan menampilkan beberapa menu seperti data ksm, data rumah, komplementaritas, asset dan kepemilikan, dan data anggota.

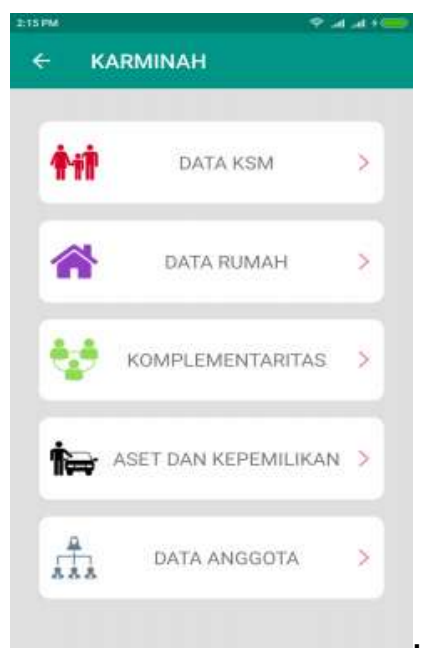

Gambar 5 Halaman Data PKH
Tampilan Web Based Manajemen Pengolah Data Admin PKH

\section{Manajemen Data PKH}

Pada halaman aplikasi menampilkan seluruh informasi data PKH yang ditampilkan dalam satu tabel. Tabel terdapat menu tambah data, export excel, pencarian data, tombol aksi seperti detail dan non aktif.

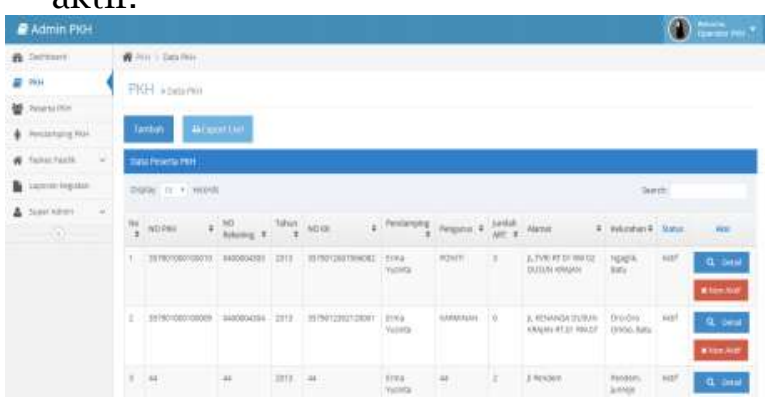

Gambar 6 manajemen Data PKH

\section{Manajemen Peserta PKH}

$$
\text { Pada halaman aplikasi }
$$

menampilkan seluruh informasi peserta PKH yang ditampilkan dalam satu tabel. Tabel terdapat menu pencarian data dan tombol aksi view detail.

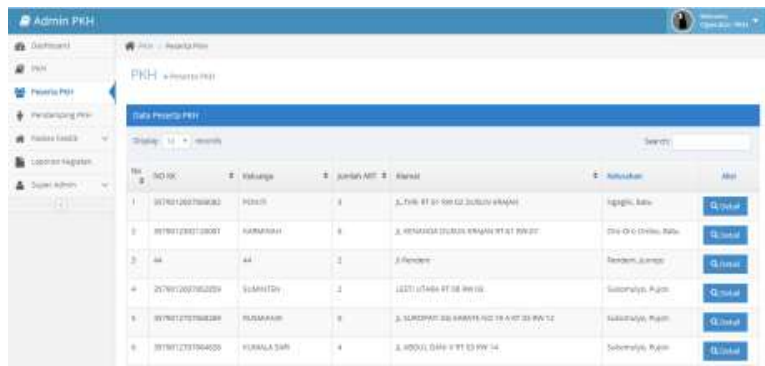

Gambar 7 manajemen Peserta PKH

3. Laporan Kegiatan

$\begin{array}{ccc}\text { Pada halaman } & \text { aplikasi } \\ \text { menampilkan } & \text { seluruh } & \text { laporan }\end{array}$

kegiatan yang ditampilkan dalam satu tabel. Laporan ditampilkan berdasarkan kegiatan yang telah di inputkan pendamping saat melakukan survey peserta PKH. 


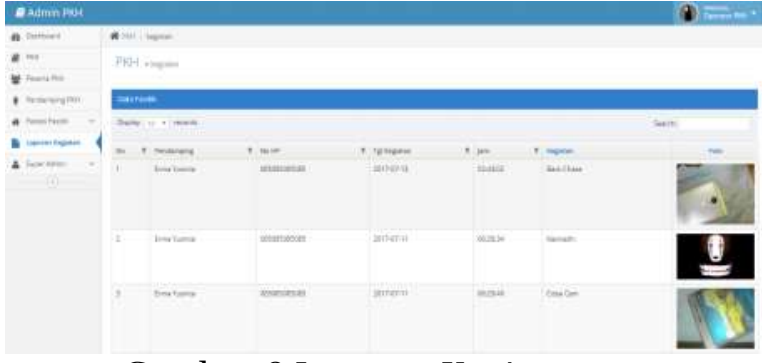

Gambar 8 Laporan Kegiatan

\section{PENGUJIAN}

Pengujian User Acceptance Test (UAT)

Pengujian User Acceptance Test (UAT) dilakukan oleh end - user dimana user tersebut adalah operator / admin PKH dan pendamping PKH yang langsung berinteraksi dengan sistem dan dilakukan verifikasi apakah fungsi yang ada telah berjalan sesuai dengan kebutuhan atau fungsinya. Pengujian dilakukan oleh 3 orang responden yaitu, 2 admin dan 1 pendamping PKH.

Adapun hasil perhitungan observasi operator / admin dan pendampingan PKH dapat dilihat dibawah ini:

1. Operator / Admin PKH

Diketahui : Diterima

$$
=1
$$

Ditolak

$$
=0
$$

Total nilai maksimal $=2$

Ditanya : Bagaimana kesimpulannya?

Jawab : 2 pertanyaan dijawab diterima.

Maka :

$\frac{(2(1)+0(0))}{\text { Total nilai maksimal }} \quad X \quad 100 \%=\frac{2 \times 100 \%}{2}=100 \%$

Dihasilkannya angka 100\% berarti menyimpulkan hak akses admin PKH dalam modul mempunyai tingkat kesesuaian yang sangat tinggi karena ini telah diuji secara langsung oleh admin.

2. Pendamping

Diketahui : Diterima

Ditolak

$$
\begin{aligned}
& =1 \\
& =0
\end{aligned}
$$

Total nilai maksimal $=7$

Ditanya : Bagaimana

kesimpulannya?

Jawab : 7 pertanyaan dijawab diterima.

$$
\begin{array}{cl}
\text { Maka } & : \\
\frac{(7(1)+0(0))}{\text { Total nilai maksimal }} & \text { X }
\end{array}
$$

Dihasilkannya angka 100\% berarti menyimpulkan hak akses pendamping PKH dalam modul mempunyai tingkat kesesuaian yang sangat tinggi karena ini telah diuji secara langsung oleh Pendamping PKH.

Adapun hasil perhitungan kuesioner admin, dan pendamping dapat dilihat dibawah ini:

$$
\begin{aligned}
& \text { 1. Admin } \\
& \text { Diketahui : STS } \\
& =1 \\
& =2 \\
& =3 \\
& S \\
& =4 \\
& =5 \\
& \begin{array}{ccr} 
& \text { Total } & \text { nilai } \\
\text { maksimal } & =80 & \text { : Bagaimana }
\end{array} \\
& \text { kesimpulannya? } \\
& \text { Jawab : } 7 \mathrm{~S}, 13 \mathrm{SS} \\
& \text { Maka } \\
& \frac{(7(4)+13(5))}{\text { Total nilai maksimal }} \quad X \quad 100 \%=\frac{73 \times 100 \%=91,2 \%}{80}
\end{aligned}
$$

Hasil perhitungan menghasilkan angka 91,2\% dapat disimpulkan bahwa acceptance admin terhadap sistem masuk kategori tinggi.

2. Pendamping

$$
\begin{array}{ll}
\begin{array}{ll}
\text { Diketahui } \\
=1
\end{array} & \text { : STS } \\
=2 & \text { TS } \\
=3 & \text { B } \\
=4 & \text { S } \\
& \text { SS }
\end{array}
$$

\section{SS}$$
=5
$$$$
\text { Total nilai maksimal }=125
$$$$
\text { Ditanya : Bagaimana }
$$
kesimpulannya?

Jawab $\quad: 8 \mathrm{~S}, 14 \mathrm{SS}$

Maka 


$$
\frac{8(4)+14(5))}{\text { Total nilai maksimal }} \times \quad 100 \%=102 \times \frac{100 \%}{125}=81,6 \%
$$

Hasil perhitungan menghasilkan angka $81.6 \%$ dapat disimpulkan bahwa acceptance pendamping terhadap sistem masuk kategori tinggi.

Berdasarkan hasil dari pengujian User Acceptance Test (UAT) dapat ditarik kesimpulan bahwa rata-rata persentase dari hasil lembar kuesioner yang dilakukan oleh 2 operator / admin dan 1 pendamping sebesar $86,4 \%$, berarti sistem sudah mendapatkan kesesuaian dengan kebutuhan Instansi UPPKH Dinas Sosial dan Tenaga Kerja Kota Batu.

Hasil lembar kuesioner dari kedua user yaitu 2 operator / admin dan 1 pendamping diperoleh persentase sebesar 100\%. Ini berarti modul telah sesuai dengan kondisi saat user menggunakan aplikasi mobile survey. User memperoleh kemudahan dalam penggunaan. Sehingga, aplikasi mobile survey sudah memperoleh tingkat kepuasan (satisfaction) yang tinggi. Selain itu sudah tidak ditemukan tautan yang rusak dalam sistem.

\section{Kesimpulan}

Dari hasil penelitian pada tugas akhir kali ini, dapat diambil kesimpulan bahwa:

1. Aplikasi mobile survey pendamping PKH berbasis android berfungsi dengan baik dan bebas dari kesalahan sintaks dan secara fungsional mengeluarkan hasil yang sesuai dengan yang diharapakan.

2. Aplikasi web based admin dan pendamping $\mathrm{PKH}$ berfungsi dengan baik dan bebas dari kesalahan sintaks dan secara fungsional mengeluarkan hasil yang sesuai dengan yang diharapkan.

3. Rata-rata persentase dari hasil lembar kuesioner yang dilakukan oleh 2 admin dan 1 pendamping PKH sebesar $86,4 \%$, berarti aplikasi mobile survey sudah mendapatkan kesesuaian dengan kebutuhan Instansi UPPKH Dinas Sosial dan Tenaga Kerja Kota Batu.
4. Hasil lembar kuesioner dari dua user yaitu 2 operator / admin dan 1 pendamping $\quad \mathrm{PKH}$ diperoleh persentase sebesar 100\%. Berarti aplikasi mobile survey telah sesuai dengan kondisi saat user digunakan.

\section{DAFTAR PUSTAKA}

H. Wijayanto, D. G. Suharto, and R. H. Haryanti, "Analisis Implementasi Perlindungan Sosial Lanjut Usia oleh Dinas Sosial Tenaga Kerja dan Transmigrasi Kota Surakarta," pp. 1-16.

A. Lutfi and H. Wafi, "Program Keluarga Harapan Berbasis WEB ( Studi Kasus: Peserta Program Keluarga Harapan Kabupaten Lombok Barat ) Kata Kunci:," vol. 12, no. 4, pp. 33-36, 2011.

K. Isnaini Kholif and I. Noor, "Implementasi Program Keluarga Harapan (PKH) Dalam Menanggulangi Kemiskinan Di Kecamatan Dawarblandong Kabupaten Mojokerto," J. Adm. Publik, vol. 2, no. 4, p. 709714.

M. Athoillah, "Mobile Berbasis Android Untuk," vol. 1, no. January, pp. 1-6, 2014.

A. Dharmawan and H. A. Ismail, "Aplikasi Pengenalan Budaya Indonesia pada Sekolah DASAR Kristen 3 YSKI Berbasis Android," no. 1, 2015.

S. N. Anwar, "Perancangan Dan Implementasi Aplikasi Mobile Semarang Guidance Pada Android," J. Teknol. Inf. Din., vol. 20, no. 1, pp. 148-158, 2015.

M. Burrakhman, I. F. Astuti, and D. M. Khairina, "Rancang Bangun Sistem Informasi Donor Darah Berbasis Web ( Studi Kasus: Unit Kegiatan Mahasiswa Korps Sukarela Universitas Mulawarman )," vol. 11, no. 1, 2016.

A. Warda, P. Putra, A. Bhawiyuga, and M. Data, "Implementasi Autentikasi JSON Web Token ( JWT ) Sebagai Mekanisme Autentikasi Protokol MQTT Pada Perangkat 
NodeMCU," vol. 2, no. 2, pp. 584-593, 2018.

Sejarah Android, "Universitas Sumatera Utara," no. September 2007, 2012.

PKH, "Buku Kerja Pendamping \& Operator PKH Tahun 2015," pp. 0-12, 2014.

T. Urrohman, L. A. Muharom, S. S. Mudafiq, R. Pratama, and S.
Kom, "Implementasi Teknologi Web Service Terhadap Pengembangan Sistem Informasi Akademik Mahasiswa Universitas Muhammadiyah Jember."

Septadi Nugraha, "Perancangan Aplikasi Pemutar Musik Beserta Penampil Lirik Musik Berbasis Android," 2016. 